Op in ion paper

urn:1sid:zoobank.org:pub:68F7AC91-1ADD-4A1E-8C5B-6F1CDCDC9DD4

\title{
Biological Systematics in the Evo-Devo era
}

\author{
Alessandro MINELLI \\ University of Padova, Department of Biology, Via Ugo Bassi 58 B, I -35131 Padova, Italy \\ E-mail: alessandro.minelli@unipd.it \\ urn:Isid:zoobank.org:author:D9FA639F-7538-441C-9572-032FD6C4EEDE
}

\begin{abstract}
Evolutionary developmental biology (evo-devo) suggests a distinction between modular and systemic variation. In the case of modular change, the conservation of the overall structure helps recognizing affinities, while a single, fast evolving module is likely to produce a bonanza for the taxonomist, while systemic changes produce strongly deviating morphologies that cause problems in tracing homologies. Similarly, changes affecting the whole life cycle are more challenging than those limited to one stage. Developmental modularity is a precondition for heterochrony. Analyzing a matrix of morphological data for paedomorphic taxa requires special care. It is, however, possible to extract phylogenetic signal from heterochronic patterns. The taxonomist should pay attention to the intricacies of the genotype $\rightarrow$ phenotype map. When using genetic data to infer phylogeny, a comparison of gene sequences is just a first step. To bridge the gap between genes and morphology we should consider the spatial and temporal patterns of gene expression, and their regulation. Minor genetic change can have major phenotypic effects, sometimes suggesting saltational evolution. Evo-devo is also relevant in respect to speciation: changes in developmental schedules are often implicated in the divergence between sympatric morphs, and a developmental modulation of 'temporal phenotypes' appears to be responsible for many cases of speciation.
\end{abstract}

Keywords. genotype $\rightarrow$ phenotype map; heterochrony; saltational evolution; speciation; temporal phenotype

Minelli A. 2015. Biological systematics in the Evo-Devo era. European Journal of Taxonomy 125: 1-23. http:// dx.doi.org/10.5852/ejt.2015.125

\section{Introduction}

In the last two centuries, the relationships between biological systematics and developmental biology have widely fluctuated. Looking at these relationships from the vantage point of systematics, the basic fact is that the vast majority of taxa have always been diagnosed on adult characters only, especially in the case of species and lower supraspecific taxa. Problems with earlier stages are of different nature, among which:

- objectively limited range of variation, compared with characters only displayed by the adult - think of copulatory organs and secondary sexual characters in animals, or flower and fruit traits in flowering plants

- inadequate presence of non-adult specimens in collections, except for select groups such as amphibiotic insects 
- lack of information about the relationships between stages (what is the adult of this larva, or juvenile, and vice versa)

- lacking or limited interest in a precise identification of non-adult specimens

- scattered but disquieting evidence that juveniles or larvae may eventually suggest a different pattern of relationships than the corresponding adults (e.g., brassoline nymphalids (Penz et al. 2013) and chalcosiine zygaenids (Yen et al. 2005) among the Lepidoptera; Staphyliniformia (Beutel \& Leschen 2005) and melolonthine scarabs (Allsopp \& Lambkin 2006) among the Coleoptera; 'nematocerans' (Oosterbroek \& Courtney 1995), sabethine mosquitoes (Judd 1998) and sepsids (Meier 1996) among the Diptera; see also a critical discussion in Meier \& Lim (2009)). The problem is worsened by the lack of a sound theoretical background against which to look for a satisfactory resolution of this conflict

To be sure, none of these difficulties should be taken as universal and unanswerable. In particular, it is fair to remark:

- the abundance of useful diagnostic characters, other than those found in the adults, that are exhibited by non-adult specimens in many groups - exemplary are dragonflies and some groups of Lepidoptera

- the taxa of which non-adult specimens are much more accessible than the corresponding (often unknown) adults, and offer adequate diagnostic characters upon which species description and also a generic and suprageneric classification can be based; this is the case of many families of mites (a good example, relative to the erythraeid genus Leptus Latreille, 1796, is Southcott 1992), the species of which are routinarily described on larvae

More than at lower taxonomic levels, information about early ontogenetic stages has often been regarded as informative of affinities among major lineages. This has even contributed to the erection of supraphyletic assemblages, the names of which explicitly refer to developmental processes, such as Protostomia and Deuterostomia. An obvious great success of the strategy of inferring kinship from the shared possession of early developmental traits was the recognizion by Kowalewski (1866) of the close affinities of vertebrates with what we now acknowledge as the non-vertebrate chordates. Curiously, exactly in the same year Haeckel (1866) formulated his biogenetic law, according to which phylogeny recapitulates ontogeny. There is no need to summarize here the history of the fading acceptance of Haeckel's principle in the following decades. The interested reader is referred to Gould's (1977) book for a detailed account. It is, however, fair to mention here that, despite the increasing disrepute into which falls the biogenetic law, an interest for ontogeny survived nevertheless in comparative biology and, specifically, in systematics. An ontogenetic criterion to establish homology between features of two different organisms is present indeed in Remane's (1952) classic (pre-cladistic) approach to comparative anatomy, and was suggested by Hennig (1966) as a potential way to identify character polarity, a key step in reconstructing phylogeny.

A major conceptual limit of all these approaches was, however, the lack of a comprehensive scheme within which to interpret the relationships between development and evolution. Ironically, despite obvious progress in both fields, the problem effectively worsened during the central decades of the past century, because of the lack of dialogue between evolutionary biology and developmental biology (Amundson 2005). A renewed interested in the relationships between ontogeny and phylogeny or, more generally, between developmental biology and evolutionary biology, emerged eventually after the publication of Gould's (1977) book, significantly titled Ontogeny and Phylogeny, and rapidly consolidated, first of all around the rapidly successful growth of comparative developmental genetics witness Raff \& Kaufman's (1983) landmark volume on Embryos, Genes and Evolution. Soon thereafter, the new discipline of evolutionary developmental biology (more popular under the nickname of evodevo) emerged, its name deriving from the title of Hall's (1992) well-targeted book. 
Today, we can characterize evolutionary developmental biology as a very active frontier of the life sciences. A perception of its scope and research agenda can be obtained by a perusal of books such as Hall (1998) and Hall \& Olson (2003) or, perhaps more sizeably, by browsing the volumes of the few dedicated journals launched thus far (Evolution \& Development; Journal of Experimental Zoology (Molecular and Developmental Evolution); Evo-Devo). It must be acknowledged that evo-devo's boundaries with respect to the parent disciplines - evolutionary biology and developmental biology are still far from being well-defined (see, e.g., Arthur 2002; Müller 2008), partly because evo-devo itself has stimulated a revisitation of the internal structure and research scope of both developmental biology (e.g., Minelli \& Pradeu 2014) and evolutionary biology (e.g., Pigliucci \& Müller 2010).

The consequences of the advent of evo-devo for a revisitation of the conceptual foundations and the improvement of practice in taxonomy are multiple and potentially far-reaching, as numerous examples demonstrate, some of which are discussed in this article. However, to date the issue has been explicitly and comprehensively addressed only by a few authors (Telford \& Budd 2003; Cracraft 2005; Minelli 2007, 2009, in press; Minelli et al. 2007; Minelli \& Fusco 2012).

Before surveying, in the remaining of this article, key areas in which biological systematics can benefit from intellectual exchange with evo-devo, it is fair to mention that evo-devo, in turn, necessitates help from taxonomy. At the most fundamental level, taxonomy is needed to get a correct identification of the species used in experimental research. This is a far from marginal point, not only because many experimental biologists do not care enough for ascertaining the identity of the organisms used in the lab, especially when these belong to taxa very numerous in species and taxonomically difficult, but also because of the widespread occurrence of cryptic species that can be taken apart and eventually given a name only following adequate specialist study. Emblematic is the case of the ascidian Ciona intestinalis (Linnaeus, 1767). Only five years after its genome sequence was published (Dehal et al. 2002), it was realized that the stocks labeled with this name and held in the labs in different parts of the world actually belonged to two different species, reproductively isolated but hardly distinguishable on morphological traits (Iannelli et al. 2007). Multiple species have also been treated as one in the case of the leech Helobdella triserialis (E. Blanchard, 1849), another popular model species (Siddall \& Borda 2003; Bely \& Weisblat 2006; Weisblat \& Kuo 2009; Kutschera et al. 2013).

The choice of new model species is another problem in relation to which taxonomy - or, more explicitly, phylogenetics - is sometimes called for help by biologists interested in the evolution of development. This choice, however, is generally misguided, being based on misconceptions about phylogenetics and character evolution (discussed in Jenner 2006; Minelli \& Baedke 2014).

\section{Developmental genes and phenotype}

The so-called developmental genes, i.e., the genes with better documented effects on the control of development, have attracted interest as potential sources of useful phylogenetic information. Several studies have focused on the Hox genes, an obvious choice in view of their role in controlling major aspects of the overall body architecture such as the orderly sequence of body features along the anteroposterior body axis. For example, Hox gene sequences have been used in reconstructing the relationships among bilaterian phyla (de Rosa et al. 1999; Balavoine et al. 2002; Passamaneck \& Halanych 2004; Hueber et al. 2013), or to investigate phylogeny within large phyla (e.g., Arthropoda: Cook et al. 2001; Janssen et al. 2014).

The path is long, however, from the gene sequence to a morphological phenotype somehow depending on its expression. 
The relationships between genotype and phenotype (the so-called genotype $\rightarrow$ phenotype map) are now largely acknowledged as complex and non-linear (e.g., Alberch 1991; Altenberg 1995; West-Eberhard 2003; Pigliucci 2010; Wagner \& Zhang 2011). In other terms, rarely, if ever, does one gene correspond to one phenotypic trait, and vice versa. As a rule, a diversity of phenotypic traits is affected by the expression of one gene (pleiotropy), and different genes, or genetic cascades, may translate into undistinguishable phenotypes (convergence and/or redundancy).

This is exactly the place where evo-devo, with its focus on comparative patterns of expression of developmental genes, can play an important role in the service of systematics.

Next to comparing gene sequences, we can in fact move to compare gene expression patterns, in order to trace homologies, especially in cases where morphological evidence does not seem to be conductive to a definitive assessment. Interesting results have been obtained, for example, by Hughes \& Kaufman (2002), Copf et al. (2003) and Angelini \& Kaufman (2005) in tracing homologies between body regions of distantly related arthropod taxa by comparing expression patterns of Hox genes. The same approach was used by Jager et al. (2006) (see also Manuel et al. 2006) to align the anterior appendages of pycnogonids with those of other arthropods.

An interesting exercise of 'evo-devo cladistics' has recently been presented by Stach (2014) for the major lineages of the deuterostomes, using a matrix of data such as the number of copies of genes in each Hox paralogous group (Hoxl to Hoxl3; his characters \#\# 1, 6, 11, 16, 21, .. 61), but also Bmpexpression on the prospective oral and aboral sides of the embryo (his characters \#\# 67 and 68). Matrix entries for characters of the latter kind result from a direct translation of the homology hypotheses implicit in evo-devo studies.

As said above, the relationships between change in gene sequence and change in phenotype are anything but linear. Wray et al. (2003) distinguished the following classes of evolutionary change in gene expression:

- changes in the spatial extent of gene expression. (e.g., Schiff et al. 1992; Brunetti et al. 2001; Scemama et al. 2002)

- changes in the timing of gene expression (transcriptional heterochrony), as documented for many taxa (e.g., Wray \& McClay 1989; Kim et al. 2000; Skaer et al. 2002). For example, the bristle pattern on the notum of Diptera is regulated by the expression of the gene scute. Differences between more distantly related taxa, such as Ceratitis capitata (Wiedemann, 1824) (Tephritidae) (Wülbeck \& Simpson 2000), Drosophila melanogaster Meigen, 1830 (Drosophilidae) (Romani et al. 1989) and Calliphora vicina Robineau-Desvoidy, 1830 (Calliphoridae) (Pistillo et al. 2002) result from different regulations of the spatial expression patterns of scute, but in the presence of identical spatial regulation, differences can emerge, due to differences in the timing of this gene's expression, as revealed by the differences in the bristle pattern of Calliphora vicina compared to another calliphorid, Protophormia terranovae (Robineau-Desvoidy, 1830) (Skaer et al. 2002)

- changes in the level of gene expression. A path-breaking study on the developmental mechanisms underlying differences in beak shape among Darwin's finches (Geospiza Gould, 1837 spp.) revealed that these are caused by the differential levels of expression of just two genes ( $\mathrm{bmp} 4$ and calmodulin) (Abzhanov et al. 2004, 2006). In Drosophila Fallén, 1823, Marcellini \& Simpson (2006) found that the development of the dorsocentral bristles - whose number and spatial arrangement are extensively used in species-level taxonomy in this genus and in other Diptera - depended on a genetic regulatory element, the dorsocentral enhancer, involved in the activatation of the scute gene in a cluster of cells from which, in species such as D. melanogaster, two bristles on the posterior scutum arise. In a few species, however, e.g., D. quadrilineata Meijere, 1911, a derived state has evolved, with anterior as well as posterior dorsocentral bristles. This character state correlates with an anterior expansion of the expression domain of the scute gene. This is in turn an effect of an evolutionary change in 
MINELLI A., Biological systematics in the Evo-Devo era

the nucleotide sequence of the enhancer. The authors present this case as an example of how gene expression patterns can be modified by a simple "evolutionary tinkering" of pre-existing enhancers, thus contributing to morphological diversification.

\section{The scope of variation}

\section{Modular vs. systemic variation}

In a biology dominated by explanations of the structure of living beings in terms of adaptations, such as was the dominant perspective during much of the XIX and XX centuries, it was usual to stress the functional integration among body parts, in animals especially. This was remarkable in Cuvier's (1812) pre-evolutionary law of the correlation among parts, as much as in Darwin's (1859) view of the individual organism as the main unit of selection; the same perspective was also dominant in the Evolutionary Synthesis of mid XXth century.

Things have changed in the last few decades, largely under the impact of evolutionary developmental biology. This discipline characteristically focuses on the evolvability of organismal traits (Hendrikse et al. 2007), that is, on the arrival of the fittest rather than on the survival of the fittest. Focussing on developing systems, rather than on the adaptive value of the eventually ensuing phenotypes, invites acknowledging that a developing organism is a system of local modules dominated by specific dynamics (e.g., Wagner 1996; Schlosser \& Wagner 2003; Klingenberg 2005). Eventually, a body part, which is 'substantially' individualized in developmental terms, turns out to represent one of those units the morphologist calls homologues (Wagner 1989). In evolutionary terms, modularity is a precondition for the occurrence of heterochrony, as a loose causal and functional coupling between modules allows these to change their dynamic parameters without necessarily disrupting the whole organism's ontogeny.

However, the units of evolutionary change do not necessarily coincide with developmental modules. Changes are sometimes modular, affecting individual modules that often emerge as hot points of morphological evolution, but in other instances evolutionary change is systemic, affecting-more or less literally - the whole organism (Minelli 2015). This distinction between modular and systemic change is of utmost interest to the taxonomist.

In the case of localized, modular change, the conservation of the overall structure helps in recognizing the affinities of the involved species, and the fast evolving module is likely to produce a bonanza for the taxonomist. This is the case with the copulatory structures of a great number of insect groups, with the chewing structures (mastax) of rotifers, with the gonopods of the males of helminthomorph millipedes. The last case deserves a more detailed account.

In these millipedes, the number of walking legs varies between 32 and 375 pairs. Except for minor peculiarities of the first pair, or the first few pairs, all these walking appendages are morphologically identical in the females and in male juveniles. New pairs of legs are added at each moult. At later stages, however, the eighth pair of legs, often also the ninth, of the male undergo a unique metamorphosis (non-systemic metamorphosis; Drago et al. 2008, 2011) and are replaced in the adult by specialized sexual appendages (gonopods) used as claspers or to transfer sperm. In most millipede species, these appendages differ dramatically from walking legs, and show up a fantastic diversity of shapes, often too complex to be adequately described in words. These gonopods are by far the single most important source of taxonomic characters for millipede taxonomy.

Things are completely different wherever morphological evolution has been systemic, rather than modular. In this case, the whole body architecture is likely to have been so deeply affected as to cause great difficulty in recognizing (on morphology alone) the actual affinities of the derived lineage. Two 
conspicuous examples of systemic morphological evolution are provided by two plant groups, the riverweeds and the duckweeds. The riverweeds (family Podostemaceae) are tropical aquatic plants, whose vegetative structures deviate strongly in comparison with all other flowering plants. In the most derived species, none of the conventional vegetative parts of angiosperms are recognizable and the whole plant is more reminiscent of an alga than of a plant with roots, stem, branches and leaves. Duckweeds (Araceae: Lemnoideae) have been found to represent a basally splitting lineage within the arum family (Henriquez et al. 2014), but their vegetative structure is the most unusual among the flowering plants: the whole photosynthetic structure is represented here by an irregular disk-shaped body, or by a small cluster of such small, floating bodies, out of which one or more roots sprout out. The ultimate member of this lineage is Wolffia arrhiza (L.) Horkel ex Wimm., a simple subspherical blob of green matter, perhaps one millimeter in diameter.

The phenotypic consequences of evolvability are sometimes limited to a single developmental stage, sometimes pervasive over the whole life cycle. Think of cirripeds like Balanus da Costa, 1778 and Lepas Linnaeus, 1758, which begin the post-embryonic phase of development as typical crustacean larvae, but later change into very unusual adults whose real affinities were discovered only when their metamorphosis was first observed by Thompson $(1830,1835)$. This contrasts with organisms represented along their entire life cycle by oddly shaped stages such as the minuscule cycliophorans that live on the appendages of the Norwegian lobster: to describe their developmental stages, zoologists were forced to introduce new terms such as the Pandora larva and the Prometheus larva, because the terminology available for other animals did not offer adequate labels for these unique forms (Obst \& Funch 2003), whose phylogenetic affinities still remain problematic (Sørensen et al. 2000; Giribet et al. 2004; Neves et al. 2012).

\section{Ontogenetic patterns of variation}

Most people, a majority of biologists included, tacitly take for granted that development is a sequence of events proceeding from an egg (or a seed, a spore, a bud) towards the adult, with an accompanying increase in complexity, the latter being theoretically difficult to define, but suggested in practice, for example, by the number and diversity of cell types, or differentiated body parts (e.g., Bonner 1988; McShea 2000).

This view of development squares well with von Baer's (1828) 'law' that traced a parallelism between the ontogenetic progression throughout embryonic development and the emergence of morphological characters diagnostic of increasingly lower taxa. However, this popular view of development is conceptually unsatisfactory (Minelli 2011, 2014) and potentially misleading as a guide to extracting information of taxonomic or phylogenetic scope. In part, the problem is caused by heterochrony, a feature of comparative developmental biology of which Haeckel was already well aware and to which I will return below. But there is another aspect, only revealed by the recent advances in evo-devo. The range of variation does not regularly increase in time, beginning with egg cleavage. Irrespective of our preferences in fixing the starting point and the end of a developmental sequence, the most conservative step is not the egg (which is a very specialized cell; Boyden \& Shelswell 1959; Song et al. 2006; Minelli 2014), but a multicellular stage called the phylotypic stage (Sander 1983; Slack et al. 1993) such as the germ-band stage in arthropods and the pharyngula in vertebrates; or, perhaps more sensibly, a phylotypic period (Richardson 1995; Richardson et al. 1997).

If we track the ontogenetic pathways of representatives of a given phylum starting from the zygote, we will see them converging towards the phylotypic stage, and only moving ahead from this stage do they start diverging according to the popular, von Baerian model. The latter, eventually, has been replaced by an hourglass model, the narrowest point of which is the phylotypic stage (Duboule 1994). 
This analysis may eventually turn into a guide to searching for phylogenetically more informative stages along an ontogenetic trajectory. The conservative phylotypic stage is arguably a choice target if we are looking for characters useful to diagnose higher-level taxa, whereas for information useful in comparisons between lower taxa, e.g., species ordinarily classified in the same genus, we are advised to look elsewhere. In different groups, different developmental phases may turn out to be more variable and informative. For example, in a comparative study of the developmental sequences of many species of Niphargus Schiödte, 1847 (Crustacea: Amphipoda), Fišer et al. (2008) found that spine development and shifts in allometric growth do not occur at random times, the highest degree of heterochrony (a proxy for independence between events) being found mainly in early mid-aged instars. Similar studies on other taxa may well be rewarding.

\section{Founder evolvability and character independence}

Systematists should always try to check for the mutual independence of the traits on which a phylogenetic analysis will be performed. However, convincing evidence of independence, or of a lack of it, is not always easy to obtain. As a consequence, every bit of information, even of circumstantial nature, is welcome.

Useful suggestions can derive, for example, by examining data in the light of Flohr et al.'s (2013: 20663) concept of founder evolvability, defined "as the maximal range of derived organisms with different niches that can be accessed from the founding ancestor by mutation and recombination over an interval of evolutionary time." The authors' experiments on bacteria have demonstrated how the dynamics of adaptive radiation are constrained by the niche occupied by the founder. The principle, however, applies also to natural radiations, especially if these evolved in exclusive and adaptively demanding environments.

In the specific case of evolutionary lineages characterized by a trend towards decreasing body complexity, the principle of founder evolvability turns out to be similar to the economic principle of diminishing returns: the more you have cut away, the less remains to be further deleted in the future. This may provide a simple explanation for the trend observed in the parasitic flatworms by Brooks \& McLennan (1993). Of 1882 character transformations implied by their phylogeny, only $10.8 \%$ could be described as a loss. But it could hardly be otherwise: on the principle of diminishing returns, a high prevalence of anatomical simplification in the nodes closest to the root of the tree has arguably determined the scarcity of further losses along the tree branches.

\section{Discontinuous variation}

\section{Virtual characters}

A quite unexpected peculiarity of the genotype $\rightarrow$ phenotype map is the fact that the phenotypic expression of a gene, or gene network, can disappear for a long time, but still remain ready to resurface, following minor genetic change or a targeted external stimulus. For example, simple treatments with hormones have been shown to release the expression of complex phenotypes not known to occur today in nature. In this way, Kim et al. (2006) were able to obtain males from all-female populations of cladocerans. The treatment caused the (re)appearance of sex-specific characters that were subsequently used in taxonomic identification and phylogenetic inference. A similar treatment was applied by Glenner et al. (2008) (see also Scholtz 2008) to representatives of a crustacean clade only known for early larval stages (the so-called Y-larvae), thus obtaining more advanced developmental stages from which useful taxonomic characters could be studied. 


\section{Saltational evolution}

Irrespective of the metrics we adopt to evaluate the phenetic distance between two species, it is not always easy to distance oneself from the naïve preconception that the phenetic distance is a prima facie proxy for the age of divergence. But this is not necessarily true: both smaller changes and larger transitions happen in fact along the history of life (Orr 1998). In other words, evolution offers examples of discontinuities (cf. Frazzetta 2012) that cannot be explained as the end result of a long chain of individually small (possibly adaptive) changes.

Larger morphological discontinuities have often provided diagnostic traits of higher taxa, such as the gastropods' torsion of the visceral sac or the dramatic directional asymmetry of the flatfishes.

Before the advent of evo-devo, the very idea of saltational evolution as an explanation for macroevolutionary transitions (as suggested, for example, by Goldschmidt (1940)), was strictly banned as heretical. However, an appreciation of the nonlinear character of the genotype $\rightarrow$ phenotype map is enough to realize how major phenotypic changes can be accomplished in a leap. For example, a singlegene mutation was probably responsible for the evolution of the bilaterally symmetrical orchid flower from an ancestor with a radially symmetrical one (Theißen 2009). Similarly, a small genetic change may explain a sudden duplication of the number of leg pairs observed in scolopendromorph centipedes. Most of the $c a .700$ species of Scolopendromorpha described thus far have a fixed number of 21 pairs of legs, although a sizeable minority has 23 (the number of leg-pairs in adult centipedes is always odd). The only scolopendromorph genus from which both numbers (21 and 23) have been recorded is Scolopendropsis Brandt, 1841 and, more precisely, individuals with either 21 or 23 pairs of legs seem to coexist in S. bahiensis (Brandt, 1841). This was the whole story before the discovery of S. duplicata Chagas, Edgecombe \& Minelli, 2008, where leg-bearing segments are either 39 or 43 (Chagas et al. 2008). This is, indeed, the only major difference between the two species, the split between which is likely to be quite recent. In this case, we can hypothesize that speciation has been accompanied by a duplication of trunk segment number, a phenotypically major leap, but one that was very likely the effect of a minor change in terms of developmental control (Minelli et al. 2009).

In the flowering plants, dramatic changes in overall morphology, such as a transition from centimeter size and herbaceous habit to meter height and woody tree structure, may happen within a genus, and in such a short time as not to involve the establishment of a complete reproductive barrier. For example, within genera represented on continents by small herbaceous species, huge size and woody stem have recently evolved in species or groups of species colonizing oceanic islands. Among the many examples given by Carlquist (1974) in his extensive treatment of island floras, there are several representatives of the Asteraceae (large woody species of Bidens L. in Southern Polynesia, of Senecio L. in New Zealand and of Centaurea L. in the Canary Islands), but also conspicuous examples in Echium L. (Boraginaceae) and Euphorbia L. (Euphorbiaceae) on Madeira, the Canary Islands and Cape Verde Islands. Worthy of special attention are the Hawaiian Asteraceae usually classified in the genera Dubautia Gaudich., Wilkesia A. Gray and Argyroxiphion DC. Their, probably recent, common ancestor has been inferred to have been similar to some living shrubby Dubautia species, but this group has diversified into several distinct life forms, including the thick cushions of densely packed silvery linear leaves known as the silverswords (Argyroxiphium spp.). Habitus differences among these plants are enormous; nevertheless, they are not completely isolated reproductively, as witnessed by a hybrid between a Dubautia species and an Argyroxiphium species found in nature (Carlquist 1980). Woodiness has also evolved in other places, as in the alpine belt of the highest mountains of Africa, where some huge Senecio and Lobelia L. are found, among others. 
MINELLI A., Biological systematics in the Evo-Devo era

\section{Heterochrony and phylogenetics}

Heterochrony is defined (Klingenberg 1998) as evolutionary change in rates and timing of developmental processes. Patterns of heterochrony may contain phylogenetic signals. For example, Guralnick \& Lindberg (2001) used the timing of cell lineage events to generate a phylogenetic tree of several lophotrochozoan taxa that turned out to agree in many respects with trees based on traditional morphological characters.

The problem is how to extract from heterochronic patterns phylogenetically useful data. This problem has repeatedly been addressed since the last decade of the past century, and solutions were proposed following a revisitation of the concept of heterochrony that suggested a perspective other than the traditional one long established by the works of de Beer (1930, 1940), Gould (1977), Alberch et al. (1979), McNamara (1986, 1995), McKinney (1988) and McKinney \& McNamara (1991). This traditional approach focused on growth heterochrony, i.e., on developmental changes in size and shape relationships. Two major classes of heterochronic patterns were thus distinguished: paedomorphosis (an organism reaches sexual maturity while retaining juvenile traits, compared to its close ancestors and/or relatives) and peramorphosis (maturation is delayed and growth period is extended).

This approach does not cover the whole range of heterochronic patterns and does not even include those potentially more useful for the taxonomist. This is why Smith (1997) and Velhagen (1997) suggested a different approach, called sequence heterochrony, in which heterochrony is identified in the changes in the sequence order of developmental events within the ontogenetic sequence. Techniques to analyze sequence heterochronies are discussed, e.g., in Velhagen (1997), Richardson et al. (2001), Smith (2001, 2002, 2003), Bininda-Emonds et al. (2002, 2007), Schulmeister \& Wheeler (2004), Jeffery et al. (2005), Goswami (2007), Blomquist (2008), Harrison \& Larsson (2008), Werneburg \& Sanchez-Villagra (2009) and Wilson et al. (2010).

The taxonomist must be aware of the fact that heterochrony is sometimes noticeable even at the intraspecific level. Examples have been provided by de Jong et al. (2009) for a Lake Victoria cichlid and by Tills et al. (2011) for the pond snail, Radix balthica (Linnaeus, 1758).

\section{Paedomorphosis}

The misleading effects of paedomorphosis on phylogenetic analysis have been accurately discussed in an important study on salamander phylogeny. Wiens et al. (2005) demonstrated that most paedomorphic families had been clustered in a single clade by a previous phylogenetic analysis (Gao \& Shubin 2001) based on morphological data, largely because of the absence, in the paedomorphic lineages, of those synapomorphies that in non-paedomorphic taxa develop at metamorphosis. An additional problem was the parallel retention, in the paedomorphic lineages, of traits associated with the aquatic habitat typical of salamander larvae.

\section{Heterochrony and flowering plant taxonomy}

Most of the recent progress in evo-devo has involved metazoans, not only at the experimental level, but also in conceptual advances. There is, however, a wonderful opportunity to extend this progress to plants and, indeed, to all organisms beyond metazoans. In the case of flowering plants, in particular, the literature is full of data generated under traditional research schemes that can be fruitfully reinterpreted in the light of evo-devo. This is, specifically, the case of heterochrony. In order to stimulate research in this field, I will devote here a couple of pages to summarizing evidence demonstrating the phylogenetic signal present in heterochronic patterns in flowering plants. 


\section{Major phenotypic effects obtained through 'cheap' heterochronic changes}

In a classic paper on the role of single-gene mutations in the evolution of flowering plants, Hilu (1983) suggested, that "nonpolygenic macromutations supplemented with micromutation" can be responsible for the large morphological gaps existing between higher taxa. The phenotypic effects of heterochrony are usually small, but can occasionally be so conspicuous as to explain why genus-level distinctions have often been introduced in the past to separate groups of species that differ in one obvious trait from their closest relatives, within whose radiation they are nevertheless deeply nested. Box et al. (2008) presented a couple of interesting examples concerning the European orchids. It does not require specialist knowledge to distinguish the species traditionally ascribed to the genus Nigritella Rich. from those ascribed to Gymnadenia R. Br., but molecular evidence places the former firmly within the latter genus, suggesting a recent origin for their peculiarities in the shape of flowers and inflorescences. The same is true for the orchid known as Coeloglossum viride (L.) Hartm., which is nothing but a species of Dactylorhiza Necker ex Nevski, mainly deviating in the relative length of spur vs. labellum. In either instance, the differences formerly taken to deserve acknowledgement at the generic level turn out to be simple heterochronic effects of differences in the growth rate of two parts of the flower.

\section{Modularity and character independence}

A traditional problem in retrieving and coding information for phylogenetic analysis is how to ensure the mutual independence of characters. This problem has frequently emerged also in the recent literature on sequence heterochrony ( $c f$. the literature cited above). This difficulty, however, is reduced to a minimum wherever a body part behaves as a developmentally independent module. In plants, this has been shown, for example, in the case of the nectariferous petals of Delphinium L. (Ranunculaceae) (Guerrant 1982). In Bauhinia L. (Fabaceae) the individual petals and stamens behave as separate homologues; thus, within the genus there are species like $B$. blakeana Dunn, with 5 petals and 3 fertile stamens, alongside species like B. divaricata L., with 2 petals and 1 functional stamen only (Wunderlin 1983; Chen et al. 2010).

\section{Peramorphosis and paedomorphosis in Campanulaceae}

In the current circumscription, Campanulaceae include a clade (Lobelioideae) often segregated in the past as an independent family, Lobeliaceae. This clade is extremely diverse, especially in terms of growth form, including very small, centimeter-high herbaceous plants as well as giant woody shrubs, up to $9 \mathrm{~m}$ in height. Spectacular examples of the latter life form are the species classified in the genus Cyanea Gaudich., an Hawai'ian endemic (Givnish et al. 2009). The tallest Cyanea species grow through juvenile stages that apparently retain more of the traits of the herbaceous ancestors, thus suggesting a peramorphic trend. However, there are also Cyanea species of reduced size and juvenile habitus, which suggest an opposite, paedomorphic trend (Lammers 1990). This hypothesis deserves revisitation based on molecular evidence.

\section{Heterostyly and homoplasy}

Heterostyly is a peculiar kind of polymorphism exhibited by a number of plant species (examples are known for 199 genera in 28 plant families; Naiki 2012), where individual plants belong to one or the other of two alternative phenotypes (distyly); quite rare are species with three different morphs (tristyly). In the case of distyly, some plants produce flowers with the stylus much longer than the stamen filaments (pin phenotype), while the others produce flowers with stamen filaments much longer than the stylus (thrum phenotype). Pollination is effective only if the pollinated plant belongs to the other phenotype in respect to the pollen-producing individual. Plant species monomorphic for the relative length of stamens and stylus are said to be homostylous. In Amsinckia Lehm. (Boraginaceae), a genus which includes both homostylous and heterostylous species, heterostyly is produced by heterochrony (Li \& Johnston 2010). The growth curve for the pistil is identical in the homostylous A. vernicosa Hook. \& Arn. and in the thrum flowers of a related heterostylous species (A. furcata Suksdorf); the growth curve of the free 
MINELLI A., Biological systematics in the Evo-Devo era

stamen filament is identical in the homostylous and the pin flowers of the heterostylous species. Within the genus, heterostyly has been reconstructed as the plesiomorphic condition, which is however derived in a wider, family-wide context. But a few Amsinckia are homostylous, as a consequence of character reversal. The homostylous $A$. vernicosa has evolved from a heterostylous ancestor comparable to $A$. furcata, whereas the homostylous $A$. gloriosa Eastw. ex Suksdorf has evolved from a heterostylous ancestor comparable to $A$. douglasiana A. DC; thus, the relationship between $A$. vernicosa and $A$. gloriosa is an interesting case of heterochrony-based homoplasy.

\section{Phylogenetic signal of heterochronic patterns in the Leguminosae}

Evo-devo is probably the ultimate resource we can use to dispose of the last surviving remnants of the century-old idea that different kinds of characters are the most adequate to diagnose taxa of different levels. Not so long ago as 1984, Tucker adopted a naïve version of recapitulation to suggest an operational dichotomy between morphological and morphogenetic characters in the Leguminosae. In his scheme, traits fixed early in ontogeny, such as the order of initiation and the position of organs, should be given value at higher (subfamily, tribe) levels, and traits fixed later in ontogeny, such as size, shape, and possible fusion of petals and other organs, should instead be given value at lower (genus and species) levels. This ignores heterochrony, of which there are many examples in this clade of plants. In the end, however, heterochrony turns out to be phylogenetically informative.

Still within the legumes, for example, Grimes (1999) determined that the heterochronic separation of vegetative and reproductive growth, causing cauliflory, is a synapomorphy of the clade Zygia, whereas the so-called Inga alliance (Cojoba Britton \& Rose, Cathormion (Benth.) Hassk., Inga Miller, Macrosamanea Britton \& Rose, Zygia P. Browne) is characterized by another heterochrony, i.e., the persistent activity of its meristems, although with character reversal in the subclade Inga+Cathormion. In another study, where the unusual flower of Duparquetia orchidacea Baill. was compared to those of other legumes (Cercis canadensis L., Petalostylis labicheoides R. Br., Labichea lanceolata Benth., Dialium guineense Willd. and Tamarindus indica L.), Prenner \& Klitgaard (2008) demonstrated the effects on flower morphology of heterochronies such as anticipation or retardation of a whole whorl with respect to another, or of a single organ (e.g., a sepal or a petal) with respect to the other elements of its whorl.

Finally, Citerne et al. (2006) have shown that late development can reverse a trend apparently determined at an early developmental stage. For example, in another legume (Cadia purpurea (G. Piccioli) Aiton), a flower that initially seems to develop into a bilaterally symmetrical (zygomorphic) flower, such as one of Lupinus L., 'corrects' its reduction in symmetry and eventually matures as a radially symmetrical (actinomorphic) flower.

\section{Evo-devo revisitation of character reversal}

Another critical point in phylogenetic analysis is the plausibility of character reversal. Dollo's (1893) macroevolutionary law states that structures that are lost in evolution will not be regained. If universally true, Dollo's law would provide an important constraint on our reconstructions of phylogeny. However, a formal test of this hypothesis is possibly unfeasible; at least, ancestral character state reconstruction does not seem to offer a reliable criterion to evaluate it (Cunningham 1999). As a consequence, we should turn to empirical evidence. Indeed, there are a number of recent phylogenetic studies suggesting exceptions to Dollo's law. Wiens (2011) has offered strong evidence of the re-evolution of mandibular teeth in the frog genus Gastrotheca Fitzinger, 1843. Based on a time-calibrated phylogeny for 170 amphibian species, mandibular teeth were apparently lost in the last common ancestor of modern frogs some 230 million years ago (Mya) but have been regained in the Gastrotheca lineage in the last ca. 5-17 million years. 


\section{Evo-devo and speciation}

Speciation processes are seldom studied from the point of view of changes in developmental control and timing (e.g., Naisbit et al. 2003), but this perspective deserves closer attention.

\section{Developmental evolution and sympatric speciation}

In several plant and animal species, two or more well-defined 'morphs' occur in the same area (the same basin, in the case of aquatic organisms), with alternative phenotypes generally confined to different habitats (e.g., Landry et al. 2007). The question is, how two or more morphs of the same species (up to four, e.g., the deep-, shallow-, river- and bay spawning morphs of the whitefish Coregonus lavaretus (Linnaeus, 1758) in Lake Femund, Norway; Østbye et al. 2005) can co-exist indefinitely in conditions of strict or approximate sympatry. Far from being an exceptional case, this multiplicity of syntopic morphs is usual in the salmonids of the genus Coregonus Linnaeus, 1758 in lakes of eastern North America (Pigeon et al. 1997) and the Central Alps (Douglas et al. 2005). The morphs found in one basin have demonstrably differentiated independently of a parallel divergence in other basins.

Changes in the regulation of ontogeny are largely responsible for the differences between sympatric morphs. Differences in the time required by the embryo to develop till hatching (Rogers \& Bernatchez 2006) are often involved, together with differential gene expression throughout the entire embryonic and early post-embryonic development. After hatching, differences in gene expression between sympatric morphs are even more conspicuous (Nolte et al. 2009). In another case, during embryonic development the transcriptome of two sympatric morphs was nearly identical, but defects in the hybrids between them suggested extensive disruption of regulatory control of gene expression, apparently affecting over 2000 genes, including crucial developmental genes (Renaut \& Bernatchez 2011).

\section{Developmental Timing and Speciation}

The importance of evolutionary developmental biology in addressing taxonomic questions is greatly increased if we open evo-devo's scope from the exclusive consideration of development and evolution of morphology to the additional consideration of the developmental control and evolution of temporal phenotypes (Minelli \& Fusco 2012). Temporal differences in the life cycle are indeed often important in ensuring prezygotic isolation between newly divergent populations. Alexander \& Bigelow (1960) used the term 'allochronic speciation' for those cases of sympatric speciation where temporal differences in the life cycles foster the isolation between two divergent populations. The plausibility of this scenario is strongly supported by well-documented cases of either individual or geographic variation in life history traits that would easily lead to temporal isolation of initially conspecific populations.

For example, populations with egg diapause and populations without egg diapause co-exist in the North-American crickets Eunemobius carolinus (De Geer, 1773), Miogryllus verticalis (Serville, 1838) and Teleogryllus commodus (F. Walker, 1869). In other crickets (Allonemobius fasciatus (De Geer, 1773), Oecanthus niveus (De Geer, 1773) and Oe. quadripunctatus Beutenmüller, 1894) the number of generations per year varies between 1 and 3 according to the population (Alexander 1968).

Individual variation in life history schedule is known for the North American cicadas of the genus Magicicada Davis, 1925, whose short adult season is usually reached at either 13 (e.g., M. tredecim (Walsh \& Riley, 1868), M. tredecassini Alexander \& Moore, 1962, M. tredecula Alexander \& Moore, 1962) or 17 years of age (e.g., M. septendecim (Linnaeus, 1758), M. cassinii (Fisher, 1852), M. septendecula Alexander \& Moore, 1962). Interestingly, there are occasional records of 13-year cicadas emerging later than expected, but exactly 4 years later, that is, as 17-year cicadas (Marshall et al. 2011). Additionally, phylogeny suggests a 13-year cycle as the primitive condition in this clade, with three independent transitions to a 17 -year cycle. An example of closely related, parapatrically distributed 
MINELLI A., Biological systematics in the Evo-Devo era

species with different developmental length are the 17-year M. septendecim and the 13-year M. tredecim (Marshall \& Cooley 2000). A detailed discussion of developmental plasticity and speciation in these cicadas was provided by West-Eberhard (2003).

Phenologically distinct populations with parapatric distribution are also known for the pine bark bug Aradus cinnamomeus Panzer, 1806 (Heliövaara et al. 1988). Maturity is usually reached by this hemipteran at the age of 2 years and individual populations are known to mature synchronously, some in the odd, some in the even years. Odd-year bugs are occasionally found in the even-year area, but are very rare, as are occasional even-year bugs in odd-year populations. Parapatric populations reaching maturity in alternate years are thus virtually isolated, reproductively, but the whole picture is complicated by the existence of peripheral populations with a 3-year life cycle.

In some flowering plants, seasonal dimorphism or polymorphism has been described, for example in several genera of the Orobanchaceae such as Odontites Ludwig, Euphrasia L., Melampyrum L. and Rhinanthus L. (e.g., de Soó \& Webb 1972), but also in Gentianella Moench (Gentianaceae) (Pritchard \& Tutin 1972; Lennartsson 1997) and in Solidago L. (Asteraceae) (e.g., Pors \& Werner 1989). In Rhinanthus, a discontinuity between early- and late-flowering plants has long been interpreted as largely due to haymaking, at least in high altitude localities where this is done only once or twice per year; this may have helped in reducing the potential gene flow between early- and late-flowering phenotypes, between which morphological differences would have rapidly accumulated (see, however, Briggs \& Walters (1997) for a critical assessment of this case). Flora Europaea authors responsible for these genera (e.g., de Soó \& Webb 1972; Pritchard \& Tutin 1972) have provided keys and descriptions for all the best characterized seasonal phenotypes in these genera without attempting to assess their taxonomic status. In a more recent study on Gentianella species, however, Lennartsson (1997) suggests that one and the same (macro)species can be represented in some areas by a single, long flowering and morphologically variable form, in other areas by two sympatric forms, phenologically distinct and morphologically distinguishable. The latter condition may eventually represent an incipient stage of speciation. What matters in the context of our analysis is the fact that these alternative phenotypes are produced by a different developmental regulation of flowering time.

\section{Acknowledgements}

I am very grateful to Henrik Enghoff and Koen Martens for their invitation to write this review paper and to an anonymous referee for the useful suggestions on a previous version.

\section{References}

Abzhanov A., Kuo W.P., Hartmann C., Grant B.R., Grant P.R. \& Tabin C.J. 2006. The calmodulin pathway and evolution of elongated beak morphology in Darwin's finches. Nature 442: 563-567. http://dx.doi.org/10.1038/nature04843

Abzhanov A., Protas M., Grant B.R., Grant P.R. \& Tabin C.J. 2004. Bmp4 and morphological variation of beaks in Darwin's finches. Science 305: 1462-1465. http://dx.doi.org/10.1126/science.1098095

Alberch P. 1991. From genes to phenotype: dynamical systems and evolvability. Genetica 84: 5-11. http://dx.doi.org/10.1007/BF00123979

Alberch P., Gould S.J., Oster G. \& Wake D. 1979. Size and shape in ontogeny and phylogeny. Paleobiology 5: 296-317.

Alexander R.D. 1968. Life cycle origins, speciation, and related phenomena in crickets. Quarterly Review of Biology 43: 1-41. 
Alexander R.D. \& Bigelow R.S. 1960. Allochronic speciation in field crickets, and a new species, Acheta veletis. Evolution 14: 334-346. http://dx.doi.org/10.2307/2405976

Allsopp P.G. \& Lambkin C.L. 2006. Canegrubs and cladistics: what story do adult, larval and ecological characters tell? Australian Journal of Entomology 45: 55-66. http://dx.doi.org/10.1111/j.1440$\underline{6055.2006 .00511 . x}$

Altenberg L. 1995. Genome growth and the evolution of the genotype-phenotype map. In: Banzhaf W. \& Eeckman F.H. (eds) Evolution and Biocomputation. Computational Models of Evolution: 205-259. Springer, Berlin.

Amundson R. 2005. The Changing Role of the Embryo in Evolutionary Thought: Roots of Evo-Devo. Cambridge University Press, Cambridge.

Angelini D.R. \& Kaufman T.C. 2005. Comparative developmental genetics and the evolution of arthropod body plans. Annual Review of Genetics 39: 95-119. http://dx.doi.org/10.1146/annurev. genet.39.073003.112310

Arthur W. 2002. The emerging conceptual framework of evolutionary developmental biology. Nature 415: 757-764. http://dx.doi.org/10.1038/415757a

Balavoine G., de Rosa R. \& Adoutte A. 2002. Hox clusters and bilaterian phylogeny. Molecular Phylogenetics and Evolution 24: 366-373. http://dx.doi.org/10.1016/S1055-7903(02)00237-3

Bely A.E. \& Weisblat D.A. 2006. Lessons from leeches: a call for DNA barcoding in the lab. Evolution \& Development 8: 491-501. http://dx.doi.org/10.1111/j.1525-142X.2006.00122.x

Beutel R.G. \& Leschen R.A.B. 2005. Phylogenetic analysis of Staphyliniformia (Coleoptera) based on characters of larvae and adults. Systematic Entomology 30: 510-548. http://dx.doi.org/10.1111/j.1365$\underline{3113.2005 .00293 . x}$

Bininda-Emonds O.R.P., Jeffery J.E., Coates M.I. \& Richardson M.K. 2002. From Haeckel to eventpairing: the evolution of developmental sequences. Theory in Biosciences 121: 297-320. http://dx.doi. org/10.1007/s12064-002-0016-5

Bininda-Emonds O.R.P., Jeffery J.E., Sánchez-Villagra M.R., Hanken J., Colbert M., Pieau C., Selwood L., Ten Cate C., Raynaud A., Osabutey C. \& Richardson M.K. 2007. Forelimb-hindlimb developmental timing across tetrapods. BMC Evolutionary Biology 7: 182. http://dx.doi.org/10.1186/1471-2148-7-182

Blomquist G.E. 2008. Methods of sequence heterochrony for describing modular developmental changes in human evolution. American Journal of Physical Anthropology 138: 231-238. http://dx.doi. org/10.1002/ajpa.20963

Bonner J.T. 1988. The Evolution of Complexity. Princeton Univ. Press, Princeton, NJ.

Box M.S., Bateman R.M., Glover B.J. \& Rudall P.J. 2008. Floral ontogenetic evidence of repeated speciation via paedomorphosis in subtribe Orchidinae (Orchidaceae). Botanical Journal of the Linnean Society 157: 429-454. http://dx.doi.org/10.1111/j.1095-8339.2008.00794.x

Boyden A. \& Shelswell E.M. 1959. Prophylogeny: some considerations regarding primitive evolution in lower Metazoa. Acta Biotheoretica 13: 115-130. http://dx.doi.org/10.1007/BF01556648

Briggs D. \& Walters S.M. 1997. Plant Variation and Evolution. 3rd ed., Cambridge University Press, Cambridge.

Brooks D.R. \& McLennan D.A. 1993. Macroevolutionary patterns of morphological diversification among parasitic flatworms (Platyhelminthes: Cercomeria). Evolution 47: 495-509. http://dx.doi. org/10.2307/2410067 
MINELLI A., Biological systematics in the Evo-Devo era

Brunetti C.R., Selegue J.E., Monteiro A., French V., Brakefield P.M. \& Carroll S.B. 2001. The generation and diversification of butterfly eyespot color patterns. Current Biology 11: 1578-1585. http://dx.doi. org/10.1016/S0960-9822(01)00502-4

Carlquist S. 1974. Island Biology. Columbia University Press, New York, NY.

Carlquist S. 1980. Hawaii. A Natural History. 2nd ed., Pacific Tropical Botanical Garden, Kauai, Hawaii.

Chagas A. Jr, Edgecombe G.D. \& Minelli A. 2008. Variability in trunk segmentation in the centipede order Scolopendromorpha: a remarkable new species of Scolopendropsis Brandt (Chilopoda: Scolopendridae) from Brazil. Zootaxa 1888: 36-46.

Chen T.C., Zhang D.X., Larsen K., Larsen S.S. 2010. Bauhinia Linnaeus. In: Wu Z.Y., Raven P.H. \& Hong D.Y. (eds) Flora of China, 10: 6-21. Science Press, Beijing \& Missouri Botanical Garden Press, St. Louis, MO.

Citerne H.L., Pennington R.T. \& Cronk Q.C.B. 2006. An apparent reversal in floral symmetry in the legume Cadia is a homeotic transformation. Proceedings of the National Academy of Sciences of the United States of America 103: 12017-12020. http://dx.doi.org/10.1073/pnas.0600986103

Cook C.E., Smith M.L., Telford M.J., Bastianello A. \& Akam M. 2001. Hox genes and the phylogeny of the arthropods. Current Biology 11: 759-763. http://dx.doi.org/10.1016/S0960-9822(01)00222-6

Copf T., Rabet N., Celniker S.E. \& Averof M. 2003. Posterior patterning genes and the identification of a unique body region in the brine shrimp Artemia franciscana. Development 130: 5915-5927. http:// dx.doi.org/10.1242/dev.00835

Cracraft J. 2005. Phylogeny and evo-devo: characters, phylogeny and historical analysis of the evolution of development. Zoology 108: 345-356. http://dx.doi.org/10.1016/j.zool.2005.09.003

Cunningham C. 1999. Some limitations of ancestral character-state reconstruction when testing evolutionary hypotheses. Systematic Biology 48: 665-674. http://dx.doi.org/10.1080/106351599260238

Cuvier G. 1812. Recherches sur les ossements fossiles de quadrupèdes, où l'on rétablit les caractères de plusieurs espèces d'animaux que les révolutions du globe paraissent avoir détruites, 4 volumes. Deterville, Paris.

Darwin C. 1859. On the Origin of Species by Natural Selection, or the Preservation of Favoured Races in the Struggle for Life. John Murray, London. http://www.biodiversitylibrary.org/bibliography/87916\#/ summary

de Beer G.R. 1930. Embryology and Evolution. Clarendon Press, Oxford.

de Beer G.R. 1940. Embryos and Ancestors. Clarendon Press, Oxford.

de Jong I.M.L., Colbert M.W., Witte F. \& Richardson M.K. 2009. Polymorphism in developmental timing: intraspecific heterochrony in a Lake Victoria cichlid. Evolution \& Development 11: 625-635. http://dx.doi.org/10.1111/j.1525-142X.2009.00370.x

de Rosa R., Grenier J.K., Andreeva T., Cook C.E., Adoutte A., Akam M., Carroll S.B. \& Balavoine G. 1999. Hox genes in brachiopods and priapulids and protostome evolution. Nature 399: 772-776.

de Soó R. \& Webb D.A. 1972. Melampyrum L.; Rhinanthus L. In: Tutin T.G., Heywood V.H., Burges N.A., Moore D.M., Valentine D.H., Walters S.M. \& Webb D.A (eds.), Flora Europaea 3: 252-257, 276-280. Cambridge University Press, Cambridge.

Dehal P., Satou Y., Campbell R.K., Chapman J., Degnan B., De Tomaso A., Davidson B., Di Gregorio A., Gelpke M., Goodstein D.M., Harafuji N., Hastings K.E., Ho I., Hotta K., Huang W., Kawashima T., Lemaire P., Martinez D., Meinertzhagen I.A., Necula S., Nonaka M., Putnam N., Rash S., Saiga H., 
Satake M., Terry A., Yamada L., Wang H.G., Awazu S., Azumi K., Boore J., Branno M., Chin-Bow S., DeSantis R., Doyle S., Francino P., Keys D.N., Haga S., Hayashi H., Hino K., Imai K.S., Inaba K., Kano S., Kobayashi K., Kobayashi M., Lee B.I., Makabe K.W., Manohar C., Matassi G., Medina M., Mochizuki Y., Mount S., Morishita T., Miura S., Nakayama A., Nishizaka S., Nomoto H., Ohta F., Oishi K., Rigoutsos I., Sano M., Sasaki A., Sasakura Y., Shoguchi E., Shin-i T., Spagnuolo A., Stainier D., Suzuki MM., Tassy O., Takatori N., Tokuoka M., Yagi K., Yoshizaki F., Wada S., Zhang C., Hyatt PD., Larimer F., Detter C., Doggett N., Glavina T., Hawkins T., Richardson P., Lucas S., Kohara Y., Levine M., Satoh N. \& Rokhsar D.S. 2002. The draft genome of Ciona intestinalis: insights into chordate and vertebrate origins. Science 298: 2157-2167. http://dx.doi.org/10.1126/science.1080049

Dollo L. 1893. Les lois de l'évolution. Bulletin de la Société belge de Géologie, de Paléontologie et d'Hydrologie 7: 164-166.

Douglas M.R., Brunner P.C. \& Douglas M.E. 2005. Evolutionary homoplasy among species flocks of central Alpine Coregonus (Teleostei: Salmoniformes). Copeia 2005: 347-358.

Drago L., Fusco G., Garollo E. \& Minelli A. 2011. Structural aspects of leg-to-gonopod metamorphosis in male helminthomorph millipedes (Diplopoda). Frontiers in Zoology 8: 19. http://dx.doi. org/10.1186/1742-9994-8-19

Drago L., Fusco G. \& Minelli A. 2008. Non-systemic metamorphosis in male millipede appendages: long delayed, reversible effect of an early localized positional marker? Frontiers in Zoology 5: 5. http://dx.doi.org/10.1186/1742-9994-5-5

Duboule D. 1994. Temporal colinearity and the phylotypic progression: a basis for the stability of a vertebrate Bauplan and the evolution of morphologies through heterochrony. Development Suppl.: 135142.

Fišer C., Bininda-Emonds O.R.P., Blejec A., \& Sket B. 2008. Can heterochrony help explain the high morphological diversity within the genus Niphargus (Crustacea: Amphipoda)? Organisms Diversity and Evolution 8: 146-162. http://dx.doi.org/10.1016/j.ode.2007.06.002

Flohr R.C.E., Blom C.J., Rainey P.B. \& Beaumont H.J.E. 2013. Founder niche constrains evolutionary adaptive radiation. Proceedings of the National Academy of Sciences of the United States of America 110: 20663-20668. http://dx.doi.org/10.1073/pnas.1310310110

Frazzetta T.H. 2012. Flatfishes, turtles, and bolyerine snakes: evolution by small steps or large, or both? Evolutionary Biology 39: 30-60. http://dx.doi.org/10.1007/s11692-011-9142-7

Gao K.-Q. \& Shubin N.H. 2001. Late Jurassic salamanders from northern China. Nature 410: 574-577. http://dx.doi.org/10.1038/35069051

Giribet G., Sørensen M.V., Funch P., Kristensen R.M. \& Sterrer W. 2004. Investigations into the phylogenetic position of Micrognathozoa using four molecular loci. Cladistics 20: 1-13. http://dx.doi. org/10.1111/j.1096-0031.2004.00004.x

Givnish T.J., Millam K.C., Mast A.R., Paterson T.B., Theim T.J., Hipp A.L., Henss J.M., Smith J.F., Wood K.R. \& Sytsma K.J. 2009. Origin, adaptive radiation and diversification of the Hawaiian lobeliads (Asterales: Campanulaceae). Proceedings of the Royal Society of London, Series B, Biological Sciences 276: 407-416. http://dx.doi.org/10.1098/rspb.2008.1204

Glenner H., Høeg J.T., Grygier M.J. \& Fujita Y. 2008. Induced metamorphosis in crustacean y-larvae: Towards a solution to a 100-year-old riddle. BMC Biology 6: 21. http://dx.doi.org/10.1186/1741-7007$\underline{6-21}$

Goldschmidt R. 1940. The Material Basis of Evolution. Yale University Press, New Haven, CT. 
MINELLI A., Biological systematics in the Evo-Devo era

Goswami A. 2007. Cranial modularity and sequence heterochrony in mammals. Evolution \& Development 9: 290-298. http://dx.doi.org/10.1111/j.1525-142X.2007.00161.x

Gould S.J. 1977. Ontogeny and Phylogeny. The Belknap Press of Harvard University Press, Cambridge, MA.

Grimes J. 1999. Inflorescence morphology, heterochrony, and phylogeny in the mimosoid tribes Ingeae and Acacieae (Leguminosae: Mimosoideae). Botanical Review 65: 317-347. http://dx.doi.org/10.1007/ $\underline{\mathrm{BF} 02857753}$

Guerrant E.O.J. 1982. Neotenic evolution of Delphinium nudicaule (Ranunculaceae), a humming-bird pollinated larkspur. Evolution 36: 699-712. http://dx.doi.org/10.2307/2407883

Guralnick R.P. \& Lindberg D.R. 2001. Reconnecting cell and animal lineages: what do cell lineages tell us about the evolution and development of Spiralia? Evolution 55: 1501-1519. http://dx.doi. org/10.1111/j.0014-3820.2001.tb00671.x

Haeckel E. 1866. Generelle Morphologie der Organismen. Allgemeine Grundzüge der organischen Formen-Wissenschaft, mechanisch begründet durch die von Charles Darwin reformirte DescendenzTheorie. Reimer, Berlin. http://www.biodiversitylibrary.org/bibliography/101747\#/summary

Hall B.K. 1992. Evolutionary Developmental Biology. Chapman \& Hall, London.

Hall B.K. 1998. Evolutionary Developmental Biology. Second Edition, Chapman \& Hall, London.

Hall B.K. \& Olson W.M. 2003. Keywords and Concepts in Evolutionary Developmental Biology. Harvard University Press, Cambridge, MA \& London.

Harrison L. \& Larsson H. 2008. Estimating evolution of temporal sequence changes: a practical approach to inferring ancestral developmental sequences and sequence heterochrony. Systematic Biology 57: 378387. http://dx.doi.org/10.1080/10635150802164421

Heliövaara K., Väisänen R., Hantula J., Lokki J. \& Saura A. 1988. Genetic differentiation in sympatric but temporally isolated pine bark bugs, Aradus cinnamomeus (Heteroptera). Hereditas 109: 29-36. http://dx.doi.org/10.1111/j.1601-5223.1988.tb00178.x

Hendrikse J.L., Parsons T.E. \& Hallgrímsson B. 2007. Evolvability as the proper focus of evolutionary developmental biology. Evolution \& Development 9: 393-401. http://dx.doi.org/10.1111/j.1525$\underline{142 X .2007 .00176 . \mathrm{X}}$

Hennig W. 1966. Phylogenetic Systematics. University of Illinois Press, Urbana, IL.

Henriquez C.L., Arias T., Pires J.C., Croat T.B. \& Schaal B.A. 2014. Phylogenomics of the plant family Araceae. Molecular Phylogenetics and Evolution 75: 91-102. http://dx.doi.org/10.1016/j. ympev.2014.02.017

Hilu K.W. 1983. The role of single-gene mutations in the evolution of flowering plants. Evolutionary Biology 16: 97-128.

Hueber S.D., Rauch J., Djordjevic M.A., Gunter H., Weiller G.F. \& Frickey T. 2013. Analysis of central Hox protein types across bilaterian clades: on the diversification of central Hox proteins from an Antennapedia/Hox7-like protein. Developmental Biology 383: 175-185. http://dx.doi.org/10.1016/j. ydbio.2013.09.009

Hughes C.L \& Kaufman T.C. 2002. Hox genes and the evolution of the arthropod body plan. Evolution \& Development 4: 459-499. http://dx.doi.org/10.1046/j.1525-142X.2002.02034.x

Iannelli F., Pesole G., Sordino P. \& Gissi C. 2007. Mitogenomics reveals two cryptic species in Ciona intestinalis. Trends in Genetics 23: 419-422. http://dx.doi.org/10.1016/j.tig.2007.07.001 
Jager M., Murienne J., Clabaut C., Deutsch J., Le Guyader H. \& Manuel M. 2006. Homology of arthropod anterior appendages revealed by Hox gene expression in a sea spider. Nature 441: 506-508. http://dx.doi.org/10.1038/nature04591

Janssen R., Eriksson B.J., Tait N.N. \& Budd G.E. 2014. Onychophoran Hox genes and the evolution of arthropod Hox gene expression. Frontiers in Zoology 11: 22. http://dx.doi.org/10.1186/1742-9994-11-22

Jeffery J.E., Bininda-Emonds O.R.P., Coates M.I. \& Richardson M.K. 2005. A new technique for identifying sequence heterochrony. Systematic Biology 54: 230-240. http://dx.doi. org/10.1080/10635150590923227

Jenner R.A. 2006. Unburdening evo-devo: ancestral attractions, model organisms, and basal baloney. Development Genes and Evolution 216: 385-394. http://dx.doi.org/10.1007/s00427-006-0084-5

Judd D.D. 1998. Exploring component stability using life-stage concordance in sabethine mosquitoes (Diptera: Culicidae). Cladistics 14: 63-93. http://dx.doi.org/10.1111/j.1096-0031.1998.tb00204.x

Kim J., Kerr J.Q. \& Min G.-S. 2000. Molecular heterochrony in the early development of Drosophila. Proceedings of the National Academy of Sciences of the United States of America 97: 212-216. http://dx.doi.org/10.1073/pnas.97.1.212

Kim K., Kotov A.A. \& Taylor D.J. 2006. Hormonal induction of undescribed males resolves cryptic species of cladocerans. Proceedings of the Royal Society of London B 273: 141-147. http://dx.doi. org/10.1098/rspb.2005.3299

Klingenberg C.P. 1998. Heterochrony and allometry: the analysis of evolutionary change in ontogeny. Biological Reviews 73: 79-123. http://dx.doi.org/10.1111/j.1469-185X.1997.tb00026.x

Klingenberg C.P. 2005. Developmental constraints, modules and evolvability. In: Hallgrímsson B. \& Hall B. K. (eds) Variation: A Central Concept in Biology: 219-247. Elsevier, Burlington, MA.

Kowalewski A. 1866. Entwicklungsgeschichte der einfachen Ascidien. Mémoires de l'Académie Impériale des Sciences de St. Petersbourg (7)10: 1-119.

Kutschera U., Langguth H., Kuo D.-H., Weisblat D.A. \& Shankland M. 2013. Description of a new leech species from North America, Helobdella austinensis n. sp. (Hirudinea: Glossiphoniidae), with observations on its feeding behaviour. Zoosystematics and Evolution 89: 239-246. http://dx.doi. org/10.1002/zoos.201300010

Lammers T.G. 1990. Campanulaceae. In: Wagner W.L., Herbst D.R. \& Sohmer S.H. (eds) Manual of the Flowering Plants of Hawai' $i$ : 420-489. University of Hawaii Press, Honolulu, Hawaii.

Landry L., Vincent W.F. \& Bernatchez L. 2007. Parallel evolution of lake whitefish dwarf ecotypes in association with limnological features of their adaptive landscape. Journal of Evolutionary Biology 20: 971-984. http://dx.doi.org/10.1111/j.1420-9101.2007.01304.x

Lennartsson T. 1997. Seasonal differentiation-a conservative reproductive barrier in two grassland Gentianella (Gentianaceae) species. Plant Systematics and Evolution 208: 45-69. http://dx.doi. org/10.1007/BF00986082

Li P. \& Johnston M.O. 2010. Flower development and the evolution of self-fertilization in Amsinckia: the role of heterochrony. Evolutionary Biology 37: 143-168. http://dx.doi.org/10.1007/s11692-010-9091-6

Manuel M., Jager M., Murienne J., Clabaut C. \& Le Guyader H. 2006. Hox genes in sea spiders (Pycnogonida) and the homology of arthropod head segments. Development Genes and Evolution 216: 481-491. http://dx.doi.org/10.1007/s00427-006-0095-2

Marcellini S. \& Simpson P. 2006. Two or four bristles: functional evolution of an enhancer of scute in Drosophilidae. PLoS Biology 4 (12): e386. http://dx.doi.org/10.1371/journal.pbio.0040386 
MINELLI A., Biological systematics in the Evo-Devo era

Marshall D.C. \& Cooley J.R. 2000. Reproductive character displacement and speciation of a new species, 13-year Magicicada neotredecim. Evolution 54: 1313-1325. http://dx.doi.org/10.1111/j.0014-3820.2000. tb00564.x

Marshall D.C., Cooley J.R. \& Hill K.B.R. 2011. Developmental plasticity of life-cycle length in thirteenyear periodical cicadas (Hemiptera: Cicadidae). Annals of the Entomological Society of America 104: 443-450. http://dx.doi.org/10.1603/AN10087

McKinney M.L. (ed.) 1988. Heterochrony in Evolution: A Multidisciplinary Approach. Plenum, New York-London.

McKinney M.L. \& McNamara K.J. 1991. Heterochrony. The Evolution of Ontogeny. Plenum, New York-London.

McNamara K.J. 1986. A guide to the nomenclature of heterochrony. Journal of Paleontology 60: 4-13.

McNamara K.J. (ed.) 1995. Evolutionary Change and Heterochrony. Wiley, Chichester.

McShea D.W. 2000. Functional complexity in organisms: parts as proxies. Biology and Philosophy 15: 641-668. http://dx.doi.org/10.1023/A:1006695908715

Meier R. 1996. Larval morphology of the Sepsidae (Diptera: Sciomyzoidea), with a cladistic analysis using adult and larval characters. Bulletin of the American Museum of Natural History 228: 1-147.

Meier R. \& Lim G.S. 2009. Conflict, convergent evolution, and the relative importance of immature and adult characters in endopterygote phylogenetics. Annual Review of Entomology 54: 85-104. http:// dx.doi.org/10.1146/annurev.ento.54.110807.090459

Minelli A. 2007. Invertebrate taxonomy and evolutionary developmental biology. Zootaxa 1668: 55-60.

Minelli A. 2009. Perspectives in Animal Phylogeny and Evolution. Oxford University Press, Oxford.

Minelli A. 2011. Animal development, an open-ended segment of life. Biological Theory 6: 4-15. http:// dx.doi.org/10.1007/s13752-011-0002-6

Minelli A. 2014. Developmental disparity. In: Minelli A. \& Pradeu T. (eds) Towards a Theory of Development: 227-245. Oxford University Press, Oxford.

Minelli A. 2015. Morphological misfits and the architecture of development. In: Serrelli E. \& Gontier N. (eds) Macroevolution. Explanation, Interpretation and Evidence: 329-343. Springer, Cham, Switzerland. http://dx.doi.org/10.1007/978-3-319-15045-1_10

Minelli A. in press. Evo Devo and its significance for animal evolution and phylogeny. In: Wanninger A. (ed.) Evolutionary Developmental Biology of Invertebrates 1: Introduction, Non-Bilateria, Acoelomorpha, Xenoturbellida, Chaetognatha. Springer, Vienna.

Minelli A. \& Baedke J. 2014. Model organisms in evo-devo: promises and pitfalls of the comparative approach. History and Philosophy of the Life Sciences 36: 42-59. http://dx.doi.org/10.1007/s40656014-0004-3

Minelli A. \& Fusco G. 2012. On the evolutionary developmental biology of speciation. Evolutionary Biology 39: 242-254. http://dx.doi.org/10.1007/s11692-012-9175-6

Minelli A. \& Pradeu T. 2014. Towards a Theory of Development. Oxford University Press, Oxford.

Minelli A., Chagas A.J. \& Edgecombe G.D. 2009. Saltational evolution of trunk segment number in centipedes. Evolution \& Development 11:318-322.http://dx.doi.org/10.1111/j.1525-142X.2009.00334.x

Minelli A., Negrisolo E. \& Fusco G. 2007. Reconstructing animal phylogeny in the light of evolutionary developmental biology. In: Hodkinson T.R. \& Parnell J.A.N. (eds) Reconstructing the Tree of Life: 
Taxonomy and Systematics of Species Rich Taxa: 177-190. Taylor and Francis - CRC Press, Boca Raton, FL.

Müller G.B. 2008. Evo-devo as a discipline. In: Minelli A. \& Fusco G. (eds) Evolving Pathways. Key Themes in Evolutionary Developmental Biology: 5-30. Cambridge University Press, Cambridge.

Naiki A. 2012. Heterostyly and the possibility of its breakdown by polyploidization. Plant Species Biology 27: 3-29. http://dx.doi.org/10.1111/j.1442-1984.2011.00363.x

Naisbit R.E., Jiggins C.D. \& Mallet J. 2003. Mimicry: developmental genes that contribute to speciation. Evolution \& Development 5: 269-280. http://dx.doi.org/10.1046/j.1525-142X.2003.03034.x

Neves R.C., Kristensen R.M. \& Funch P. 2012. Ultrastructure and morphology of the cycliophoran female. Journal of Morphology 273: 850-869. http://dx.doi.org/10.1002/jmor.20025

Nolte A.W., Renaut S. \& Bernatchez L. 2009. Divergence in gene regulation at young life history stages of whitefish (Coregonus sp.) and the emergence of genomic isolation. BMC Evolutionary Biology 9: 59. http://dx.doi.org/10.1186/1471-2148-9-59

Obst M. \& Funch P. 2003. Dwarf male of Symbion pandora (Cycliophora). Journal of Morphology 255: 261-278. http://dx.doi.org/10.1002/jmor.10040

Oosterbroek P. \& Courtney G. 1995. Phylogeny of the nematocerous families of Diptera (Insecta). Zoological Journal of the Linnean Society 115: 267-311. http://dx.doi.org/10.1006/zjls.1995.0080

Orr H.A. 1998. The population genetics of adaptation: the distribution of factors fixed during adaptive evolution. Evolution 52: 935-949. http://dx.doi.org/10.2307/2411226

Østbye K., Næsje T.F., Bernatchez L., Sandlund O.T. \& Hindar K. 2005. Morphological divergence and origin of sympatric populations of European whitefish (Coregonus lavaretus L.) in Lake Femund, Norway. Journal of Evolutionary Biology 18: 683-702. http://dx.doi.org/10.1111/j.1420-9101.2004.00844.x

Passamaneck Y.J. \& Halanych K.M. 2004. Evidence from Hox genes that bryozoans are lophotrochozoans. Evolution \& Development 6: 275-281. http://dx.doi.org/10.1111/j.1525-142X.2004.04032.x

Penz C.M., Freitas A.V.L., Kaminski L.A., Casagrande M.M. \& Devries P.J. 2013. Adult and early-stage characters of Brassolini contain conflicting phylogenetic signal (Lepidoptera, Nymphalidae). Systematic Entomology 38: 316-333. http://dx.doi.org/10.1111/syen.12000

Pigeon D., Chouinard A. \& Bernatchez L. 1997. Multiple modes of speciation involved in the parallel evolution of sympatric morphotypes of lake whitefish (Coregonus clupeaformis, Salmonidae). Evolution 51: 196-205. http://dx.doi.org/10.2307/2410973

Pigliucci M. 2010. Genotype-phenotype mapping and the end of the 'genes as blueprint' metaphor. Philosophical Transactions of the Royal Society of London, Series B, Biological Sciences 365: 557-566. http://dx.doi.org/10.1098/rstb.2009.0241

Pigliucci M. \& Müller G. (eds) 2010. Evolution: The Extended Synthesis. MIT Press, Cambridge, MA.

Pistillo D., Skaer N. \& Simpson P. 2002. scute expression in C. vicina reveals an ancestral pattern of longitudinal stripes on the thorax of higher Diptera. Development 129: 563-572.

Pors B. \& Werner P.A. 1989. Individual flowering time in a goldenrod (Solidago canadensis). Field experiments show genotype more important than environment. American Journal of Botany 76: 16811688. http://dx.doi.org/10.2307/2444406

Prenner G. \& Klitgaard B.B. 2008. Towards unlocking the deep nodes of Leguminosae: floral development and morphology of the enigmatic Duparquetia orchidacea (Leguminosae, Caesalpinioideae). American Journal of Botany 95: 1349-1365. http://dx.doi.org/10.3732/ajb.0800199 
MINELLI A., Biological systematics in the Evo-Devo era

Pritchard N.M. \& Tutin T.G. 1972. Gentianella Moench. In: Tutin T.G., Heywood V.H., Burges N.A., Moore D.M., Valentine D.H., Walters S.M. \& Webb D.A. (eds), Flora Europaea 3: 63-67. Cambridge University Press, Cambridge.

Raff R.A. \& Kaufman T.C. 1983. Embryos, Genes, and Evolution. Macmillan, New York.

Remane A. 1952. Die Grundlagen des natürlichen Systems der vergleichenden Anatomie und der Phylogenetik. Geest \& Portig, Leipzig.

Renaut S. \& Bernatchez L. 2011. Transcriptome-wide signature of hybrid breakdown associated with intrinsic reproductive isolation in lake whitefish species pairs (Coregonus spp., Salmonidae). Heredity 106: 1003-1011. http://dx.doi.org/10.1038/hdy.2010.149

Richardson M.K. 1995. Heterochrony and the phylotypic period. Developmental Biology 172: 412-421. http://dx.doi.org/10.1006/dbio.1995.8041

Richardson M.K., Hanken J., Gooneratne M.L., Pieau C., Raynaud A., Selwood L. \& Wright G.M. 1997. There is no highly conserved embryonic stage in the vertebrates: implications for current theories of evolution and development. Anatomy \& Embryology 196: 91-106. http://dx.doi.org/10.1007/ $\underline{\mathrm{s} 004290050082}$

Richardson M.K., Jeffery J.E., Coates M.I. \& Bininda-Emonds O.R.P. 2001. Comparative methods in developmental biology. Zoology 104: 278-283. http://dx.doi.org/10.1078/0944-2006-00033

Rogers S.M. \& Bernatchez L. 2006. The genetic basis of intrinsic and extrinsic post-zygotic reproductive isolation jointly promoting speciation in the lake whitefish species complex (Coregonus clupeaformis). Journal of Evolutionary Biology 19: 1979-1994. http://dx.doi.org/10.1111/j.1420-9101.2006.01150.x

Romani S., Campuzano S., Macagno E.R. \& Modolell J. 1989. Expression of achaete and scute genes in D. melanogaster imaginal discs and their function in sensory organ development. Genes \& Development 3: 997-1007. http://dx.doi.org/10.1101/gad.3.7.997

Sander K. 1983. The evolution of patterning mechanisms: gleanings from insect embryogenesis and spermatogenesis. In: Goodwin B.C., Holder N. \& Wylie C.C. (eds) Development and Evolution: 137159. Cambridge University Press, Cambridge.

Scemama J.L., Hunter M., McCallam J., Prince V. \& Stellwag E. 2002. Evolutionary divergence of vertebrate Hoxb2 expression patterns and transcriptional regulatory loci. Journal of Experimental Zoology (Molecular and Developmental Biology) 294: 285-299. http://dx.doi.org/10.1002/jez.90009

Schiff N.M., Feng Y., Quine J.A., Krasney P.A. \& Cavener D.R. 1992. Evolution of the expression of the Gld gene in the reproductive tract of Drosophila. Molecular Biology and Evolution 9: 1029-1049.

Schlosser G. \& Wagner G.P. 2003. Introduction: the modularity concept in developmental and evolutionary biology. In: Schlosser G. \& Wagner G.P. (eds) Modularity in Development and Evolution: 1-11. University of Chicago Press, Chicago.

Scholtz G. 2008. Zoological detective stories: the case of the facetotectan crustacean life cycle. Journal of Biology 7: 16. http://dx.doi.org/10.1186/jbiol77

Schulmeister S. \& Wheeler W.C. 2004. Comparative and phylogenetic analysis of developmental sequences. Evolution \& Development 6: 50-57. http://dx.doi.org/10.1111/j.1525-142X.2004.04005.x

Siddall M.E. \& Borda E. 2003. Phylogeny and revision of the leech genus Helobdella (Glossiphoniidae) based on mitochondrial gene sequences and morphological data and a special consideration of the triserialis complex. Zoologica Scripta 32: 23-33. http://dx.doi.org/10.1046/j.1463-6409.2003.00098.x

Skaer N., Pistillo D. \& Simpson P. 2002. Transcriptional heterochrony of scute and changes in bristle pattern between two closely related species of blowfly. Developmental Biology 252: 31-45. 
Slack J.M.W., Holland P.W.H. \& Graham C.F. 1993. The zootype and the phylotypic stage. Nature 361: 490-492. http://dx.doi.org/10.1038/361490a0

Smith K.K. 1997. Comparative patterns of craniofacial development in eutherian and metatherian mammals. Evolution 51: 1663-1678. http://dx.doi.org/10.2307/2411218

Smith K.K. 2001. Heterochrony revisited: the evolution of developmental sequences. Biological Journal of the Linnean Society 73: 169-186. http://dx.doi.org/10.1111/j.1095-8312.2001.tb01355.x

Smith K.K. 2002. Sequence heterochrony and the evolution of development. Journal of Morphology 252: 82-97. http://dx.doi.org/10.1002/jmor.10014

Smith K.K. 2003. Time's arrow: heterochrony and the evolution of development. International Journal of Developmental Biology 47: 613-621.

Song J.L., Wong J.L. \& Wessel G.M. 2006. Oogenesis: single cell development and differentiation. Developmental Biology 300: 385-405. http://dx.doi.org/10.1016/j.ydbio.2006.07.041

Sørensen M.V., Funch P., Willerslev E., Hansen A.J. \& Olesen J. 2000. On the phylogeny of the Metazoa in the light of Cycliophora and Micrognathozoa. Zoologischer Anzeiger 239: 297-318.

Southcott R.V. 1992. Revision of the larvae of Leptus Latreille (Acarina: Erythraeidae) of Europe and North America, with descriptions of post-larval instars. Zoological Journal of the Linnean Society 105: 1-153. http://dx.doi.org/10.1111/j.1096-3642.1992.tb01228.x

Stach T. 2014. Deuterostome phylogeny - a morphological perspective. In: Wägele J.W. \& Bartolomaeus T. (eds) Deep Metazoan Phylogeny: The Backbone of the Tree of Life: 425-457. De Gruyter, Berlin.

Telford M.J. \& Budd G.E. 2003. The place of phylogeny and cladistics in Evo-Devo research. International Journal of Developmental Biology 47: 479-490.

Theißen G. 2009. Saltational evolution: hopeful monsters are here to stay. Theory in Biosciences 128: 43-51. http://dx.doi.org/10.1007/s12064-009-0058-z

Thompson J.V. 1830. On the Cirripedes or Barnacles; demonstrating their deceptive character; the extraordinary Metamorphosis they undergo, and the Class of Animals to which they indisputably belong. In: Thompson J.V., Zoological Researches, and Illustrations; or, Natural History of Nondescript or Imperfectly Known Animals 1(1): 69-82. King and Ridings, Cork.

Thompson J.V. 1835. Discovery of the Metamorphosis in the Second Type of the Cirripedes, viz. the Lepades, Completing the Natural History of these singular Animals, and Confirming Their Affinity with the Crustacea. Philosophical Transactions of the Royal Society 126: 355-358. http://dx.doi.org/10.1098/ rstl.1835.0022

Tills O., Rundle S.D., Salinger M., Haun T., Pfenninger M. \& Spicer J.I. 2011. A genetic basis for intraspecific differences in developmental timing? Evolution \& Development 13: 542-548. http://dx.doi. org/10.1111/j.1525-142X.2011.00510.x

Tucker S.C. 1984. Origin of symmetry in flowers. In: White R.A. \& Dickison W.C. (eds) Contemporary Problems in Plant Anatomy: 351-395. Academic Press, San Diego.

Velhagen W.A. Jr. 1997. Analyzing developmental sequences using sequence units. Systematic Biology 46: 204-210. http://dx.doi.org/10.1093/sysbio/46.1.204

von Baer K.E. 1828. Über Entwicklungsgeschichte der Thiere: Beobachtung und Reflexion 1. Bornträger, Königsberg.

Wagner G.P. 1989. The origin of morphological characters and the biological basis of homology. Evolution 43: 1157-1171. http://dx.doi.org/10.2307/2409354 
MINELLI A., Biological systematics in the Evo-Devo era

Wagner G.P. 1996. Homologues, natural kinds and the evolution of modularity. American Zoologist 36: $36-43$.

Wagner G.P. \& Zhang J. 2011. The pleiotropic structure of the genotype-phenotype map: The evolvability of complex organisms. Nature Reviews Genetics 12: 204-213. http://dx.doi.org/10.1038/nrg2949

Weisblat D.A. \& Kuo D.-H. 2009. Helobdella (Leech): a model for developmental studies. In: Emerging Model Organisms - a Laboratory Manual 1: 245-267. CSHL Press, Cold Spring Harbor.

Werneburg I. \& Sanchez-Villagra M.R. 2009. Timing of organogenesis support basal position of turtles in the amniote tree of life. BMC Evolutionary Biology 9: 82. http://dx.doi.org/10.1186/1471-2148-9-82

West-Eberhard M.J. 2003. Developmental Plasticity and Evolution. Oxford University Press, New York.

Wiens J.J. 2011. Re-evolution of lost mandibular teeth in frogs after more than 200 million years, and reevaluating Dollo's law. Evolution 65: 1283-1296. http://dx.doi.org/10.1111/j.1558-5646.2011.01221.x

Wiens J.J., Bonett R.M. \& Chippindale P.T. 2005. Ontogeny discombobulates phylogeny: paedomorphosis and higher-level salamander relationships. Systematic Biology 54: 91-110. http:// dx.doi.org/10.1080/10635150590906037

Wilson L.A.B., Schradin C., Mitgutsch C., Galliari F.C., Mess A. \& Sánchez-Villagra M.R. 2010. Skeletogenesis and sequence heterochrony in rodent evolution, with particular emphasis on the African striped mouse, Rhabdomys pumilio (Mammalia). Organisms Diversity and Evolution 10: 243-258. http://dx.doi.org/10.1007/s13127-010-0020-4

Wray G.A., Hahn M.W., Abouheif E., Balhoff J.P., Pizer M., Rockman M.V. \& Romano L.A. 2003. The evolution of transcriptional regulation in eukaryotes. Molecular Biology and Evolution 20: 1377-1419. http://dx.doi.org/10.1093/molbev/msg140

Wray G.A. \& McClay D.R. 1989. Molecular heterochronies and heterotopies in early echinoid development. Evolution 43: 803-813. http://dx.doi.org/10.2307/2409308

Wülbeck C. \& Simpson, P. 2000. Expression of achaete-scute homologues in discrete proneural clusters on the developing notum of the medfly $C$. capitata, suggests a common origin for the stereotyped bristle patterns of higher Diptera. Development 127: 1411-1420.

Wunderlin R.P. 1983. Revision of the arborescent Bauhinias (Fabaceae: Caesalpinioideae: Cercideae) native to middle America. Annals of the Missouri Botanical Garden 70: 95-127. http://dx.doi. org/10.2307/2399009

Yen S.H., Robinson G.S. \& Quicke D.L.J. 2005. The phylogenetic relationships of Chalcosiinae (Lepidoptera, Zygaenoidea, Zygaenidae). Zoological Journal of the Linnean Society 143: 161-341. http://dx.doi.org/10.1111/j.1096-3642.2005.00139.x

Manuscript received: 5 January 2015

Manuscript accepted: 13 April 2015

Published on: 8 June 2015

Topic editor: Koen Martens

Desk editor: Kristiaan Hoedemakers

Printed versions of all papers are also deposited in the libraries of the institutes that are members of the EJT consortium: Muséum National d'Histoire Naturelle, Paris, France; Botanic Garden Meise, Belgium; Royal Museum for Central Africa, Tervuren, Belgium; Natural History Museum, London, United Kingdom; Royal Belgian Institute of Natural Sciences, Brussels, Belgium; Natural History Museum of Denmark, Copenhagen, Denmark. 